\title{
REVITALISASI GURINDAM DUA BELAS KARYA RAJAALI HAJI SEBAGAI PENDIDIKAN BERBASIS KEARIFAN LOKAL ETNIS MELAYU
}

\author{
Lisken Sirait \\ Universitas Maritim Raja Ali Haji \\ Email: liskensirait06@gmail.com
}

\begin{abstract}
Abstrak Gurindam Dua Belas adalah puisi lama dari bumi Melayu karya Raja Ali Haji. Tulisan yang dituangkan dalam bentuk puisi lama Gurindam Dua Belas ini memiliki banyak pesan moral baik dilihat dari aspek pendidikan, agama, dan budaya. Selain sebagai ulama beliau dijuluki sebagai Bapak sastrawan sekaligus sebagai Pahlawan Nasional dari Propinsi Kepulauan Riau. Beliau menamakan Gurindam Dua Belas dikarenakan terdapat dua belas pasal yang terdiri dari dua bait, tiap bait terdiri dari dua baris kalimat dengan rima yang sama, dan merupakan satu kesatuan yang utuh. Baris pertama berisikan semacam soal atau masalah atau perjanjian dan baris kedua berisikan jawaban atau akibat dari masalah atau perjanjian pada baris pertama. Gurindam Dua Belas tidak saja terdengar indah saat diucapkan akan tetapi banyak pesan moral yang disampaikan di dalamnya seperti himbauan dan nasihat sejalan dengan ajaran agama dan pendidikan secara formal. Uniknya, isi dari Gurindam Dua Belas ini ditujukan kepada semua usia dimana ada himbauan dan nasihat terkait kewajiban anak kepada orang tua, orang tua kepada anak, kewajiban bangsawan kepada masyarakatnya, budi pekerti, nasihat, beribadah kepada Tuhan Yang Maha Esa, dan bagaimana hidup bermasyarakat yang baik. Melalui puisi Gurindam Dua Belas tersebut, Raja Ali Haji bermaksud memberikan pelajaran terkait dengan nilai, norma, dan etika yang memiliki koherensi melalui pengajaran agama, pendidikan, politik, filsafat, dan hukum.

Kata kunci: Gurindam Dua Belas, Pendidikan, Keraifan Lokal.
\end{abstract}

\section{PENDAHULUAN}

Saat ini berbagai Negara di dunia termasuk bangsa Indonesia dihadapkan dengan jaman globalisasi dan modernisasi. Banyak yang berubah dari perkembangan jaman tersebut baik secara fisik dan abstrak. Indonesia sebagai salah satu Negara yang kaya dengan berbagai jenis kearifan lokal atau bangsa yang heterogenitas tergolong dan salah satu Negara yang menerima perkembangan globalisasi.

Tidak dapat dipungkiri bahwa tidak ada alasan bagi kita untuk menoloka berbagai kemajuan jaman tersebut. Hal ini akan berimbas pada kemajuan dan ketertingalan kita dari Negaranegara lain di dunia. Namun realita yang terjadi saat ini ialah berbagai daearah di Indonesia yang memiliki berbagai kekayaan kesenian, kebudayaan, kearifan lokal lainnya ada yang mengalami degradasi.

Hal disebabkan dimana ada perkembangan jaman yang lebih cepat dibandingkan berbagai hal yang dapat dilakukan oleh pemerintah dan masyarakat sebagai antisipasi mempertahankan kearifan lokal tersebut. Tentu guna tetap mempertahankan berbagai nilai-nilai dan kearifan lokal yang meruapakan peninggalan nenek moyang kita dituntut kerja sama yang baik dari semua elemen khususnya pemerintah pusat dan daerah.

Dalam hal ini salah satu hal yang dapat dilakukan ialah dengan memberlakukan pembelajaran bgai pserta didik di sekolah formal yakni mata pelajaran kearifan lokal. Dalam hal ini sesungguhnya berbagai nilai dan kearifan lokal tida boleh diartikan dalam sebatas ilmu pengetahuan terkait budaya. Kita tahu bahwa di dalam kearifan lokal terkandung nilai-nilai yang menggambarkan identitas individu, kelompok, atau masyarakat berdasarkan faktor geografis masing-masing sebagaimana dijelaskan dalam (Kartawinata,2011).

Sejalan dengan hal tersebut salah satu hal yang menjadi kearifan lokal dari daerah Tanjungpinang Propinsi Kepulauan Riau yakni yang menjadi jargon etnis Melayu ialah Gurindam Daua Belas. Gurindam Dua Belas ini merupakan karya Raja Ali Haji seorang satrawan terkenal di amsanya dan juga seorang pemuka agama Islam. Gurindam Dua Belas ini merupakan puisi lama 
yang dimana terdiri dari empat bait dan setiap bait yakni bait pertama dan kedua adalah hal yang mengingatkan sedangkan pada baris kedua dank ke tiga ialah hal-hal apa saja yang akan terjadi jika saja nasihat itu dilanggar.

Mengingat saat ini kota Tanjungpinang menjadi salah satu pintu gerbang bagi wisatawan asing maka sangat mudah dimasuki oleh pengaruh kemajuan jaman atau globalisasi. Untuk itu, agar Gurindam Dua Belas ini tetap bisa eksis dan menjadi salah satu icon etnis Melayu maka sebaikanya dilakukan berbagai revitalsiasi oleh pemerintah daerah. Hal ini disinyalir akan semakin memperkuat jati diri etnis Melayu sebagai daerah yang penih dengan kearifan lokal dan beradat bersendikan nilai-nilai agama dan pendidikan.

Melalui kearifan lokal tersebut, masyarakat adat di Indonesia memiliki pemahaman hidup dalam mempertahankan, memperbaiki, dan mengembangkan cara pemenuhan kebutuhan dengan memperhatikan sumber daya manusia dan khususnya sumber daya alam yang ada disekelilingnya (Suryani, 2014), dari segala bentuk aktivitas masyarakat tradisional yang di lestarikan dan dipraktekkan secara turun temurun dari leluhur atau nenek moyang (Cecep, Permana, Nasution, \& Gunawijaya, 2011). Pemanfaatan kearifan lokal dapat dilihat sebagai sistem pengelolaan sumber daya alam yang digambarkan sebagai pelestarian dengan etika yang menjadi titik utama dan gagasan penting dalam pengelolaannya (Dwyer, 1994). Sehingga tindakan-tindakan itu memberikan dampak positif baik untuk masyarakat, lingkungan dan generasi mendatang.

Salah satu unsur kebudayaan menurut (Koentjaraningrat, 2009) didalamnya memuat unsur pengetahuan dan teknologi sebagai bagian dari unsur kebudayaan masyarakat. Pengetahuan dan teknologi tradisional dijelaskan sebagai gabungan pemahaman masyarakat, praktik dan keyakinan yang berkembang melalui adaptasi \& diabadikan melalui transmisi antar generasi (Friedlander, Shackeroff, \& Kittinger, 2013). Dan masih harus dibayar kepada generasi selanjutnya (Drew, 2005).

Gurindan Dua Belas yang menjadi icon bagi masyarakat etnis Melayu Tanjungpinang memberikan pemahaman akan contoh nyata dalam penerapan sikap glokalisasi. Yaitu dimana kita harus mampu bertindak lokal dengan memanfaatkan pengetahuan nenek moyang yang diwariskan, dan harus mampu pula berpikir global yang berorientasi masa depan. Dalam hal ini penerapan nilai-nilai yang terkandung dalam isi Gurindam Dua Belas harus tetap dilestarikan sebagai pembelajaran karakter berbasis kearifan lokal.

\section{KAJIAN PUSTAKA 2.1. Kearifan Lokal}

Menurut (Jim, 2002), menyatakan bahwa kearifan lokal merupakan nilai-nilai yang diciptakan, dikembangkan dan dipertahankan dalam masyarakat lokal dan karena kemampuannya untuk bertahan dan menjadi pedoman hidup masyarakatnya.

Berdasarkan defenisi di atas dalam hal ini penulis berpendapat bahwa kearifan lokal merupakan serangkain nilai-nilai yang bersifat fisik dan bastrak peninggalan nenek moyang kita, dan di dalamnya terkandung berbagai pesan dan nasihat bersendikan agama dan pendidikan. Tentu setiap daerah dalam hal ini memiliki berbagai kearifan lokal berdasarkan geografisnya dan berbeda-beda.

Dari serangkain defenisi kearifam lokal menurut pendapat ahli dan penulis tersebut maka hal ini menyampakan cara pandang bagi kita untuk tetap dapat menghargai dan merawat alam sebagai penyedia kebutuhan bagi kehidupan manusia. Setiap individu dan kelompok diminta untuk dapat mengeksploitasi kekayaan alam dengan beradab dan peduli tanpa merusaknya.

\subsection{Fungsi Kearifan Lokal}

(Sirtha, 2003) sebagaimana dikutip oleh (Sartini, 2004), menjelaskan bahwa bentukbentuk kearifan lokal yang ada dalam masyarakat dapat berupa: nilai, norma, kepercayaan, dan aturan-aturan khusus. Tentu kearifan lokal yang memiliki berbagai bentuk berpengaruh pada fungsi nya masing-masing. Berbagai fungsi dari kearifan lokal bagi masyarakat diantaranya, a) lokal wisdom dapat diajdikan sebagai bentuk konservatif guna melindungi dan menjaga berbagai kelestraian alam, b) lokal wisdom kearifan memilki fungsi dalam hal pengembangan SDM, c) pada sisi lain menjadi hal yang dapt berpotensi dalam mengembagkan berbagai kebudayaan dan iptek, d) lokal wisdom juga memiliki kegunaan sebagai petuah, trus, dan larangan bagi masyarakat terkait hal-hal yang dapat merusak ekosistem.

Maka berdasarkan defenisi lokal wisdom di atas dalam hal ini dapat dipahami bahwa kearifan lokal tersebut mengandung berbagai pesan moral, nilai dan norma, yang disampaikan melaui kebudayaan, kepercayaan masyarakat.

\subsection{Gurindam Dua Belas}

Gurindam Dua Belas adalah merupakan tulisan berbentuk puisi yang terdiri dari empatbaris. Pada baris pertama dank e dua dalam hal ini menuliskan himabuan kepada khlayak ramai dengan nilai-nilai yang bersendikan religi 
dan pendidikan. Sedangkan pada baris ke dua dan ketiga ialah apa saja yang terjadi bagi seseorang jika saja nasehat tersebut dilanggar. Dalam isi Gurindam Dua Belas ini banyak pesan moral berupa himbauan dan nasehat yang kita dapat.

\section{METODE PENELITIAN}

Metode penelitian diartikan sebagai cara ilmiah untuk mendapatkan data dengan tujuan dan kegunaan tertentu" (Sugiyono, 2013). Pada jurnal yang membahas mengenai revitalisasi Gurindam Dua Belas berbasis pendidikan kearifal ini, penulis mengungkapkan fakta-fakta yang bersumber dari study literature. Yaitu yang bersumber dari jurnal, buku, dan sumber internet yang sudah terakreditasi. Sehingga penulis membuat sebuah tulisan yang mencoba menggabungkan intisari pada tiap tulisan tersebut dengan tujuan dapat mencangkup inti keseluruhan terkait revitalisasi Gurindam Dua Belas sebagai pendidikan berbasis kearifan local. Langkah selanjutnya melakukan penyusunan hasil kajian dengan Bahasa yang mudah untuk dicerna masyarakat.

\section{TEMUAN DAN PEMBAHASAN 4.1. TEMUAN}

Etnis Melayu yang tinggal di Kota Tanjungpinang adalah bagian dari suku di Indonesia yanag memiliki banyak kekayaan kearifan lokal baik secara fisik dan abstrak atau secara tangible dan ingtangibel. Manyoritas penduduknya ialah beragam Islam dan memiliki suku Melayu akan tetapi tidak dapat dipungkiri bahwa terdapat berbagai suku-suku lainnya tinggal dan menetap di kota tersebut. Namun sebagai daerah Melayu yang kental dengan nilainilai religinya kota ini merupakan daerah yang toleransi walaupun dihuni oleh berbagai suku dan etnis lainnya.

Hal ini terjadi dimana saat ini peran dari berbagai orang tua dan lingkungan yang sarat dengan nilai-nilai agama Melayu Islam sangat membantu dalam membentuk karakter seseorang. Pada sisi lainnya ialah melalui peran pendidikan yang terus menggalakkan nilai-nilai kearifan lokal tersebut dengan bertujuan supaya tidak terjadi konflik sosial, pertentangan, kriminalisasi, dan pertikaian yang sampai mengakibatkan korban dan kerugian.

Penulis dalam hal ini berpandangan bahwa salah satu cara yang dapat dilakukan oleh pemerintah pusat dan daerah, orang tua, maupun masyarakat dalam menjaga dan mempertahankan nilai-nilai kebinnekaan itu ialah pendidikan.

\subsection{PEMBAHASAN}

Untuk tetap bisa mempertahan kan nilai-nilai dan norma yang terkandung pada kearifan loka yang terdapat di kota Tanjungpinang maka harus dilakukan pembelajaran muatan lokal terkait dengan Gurindan Dua Belas. Hal ini sangat baik dimana pada Gurindan Dua Belas ini bnayak hal yang dapat diambil sebagai bentuk himbauan dan nasehat bagi semua kalagan masyarakat.

Model pembelajaran yang dimaksud ialah dengan menerapkan mata pelajaran muatan lokal yang menyampaikan pesan -pesan moral Gurindam Dua Belas tersebut secara terintegarsi bagi peserta didik. Dalam hal ini dapat dilakukan dalam peserta didik sekolah dasar (SD), Sekolah Menengah Pertama (SMP), Sekolah Menengah Atas (SMA).Sebagai agaen sosial dalam hal ini peran dari semua masyarakat sangat dibutuhkan tidak saja pendidikan secara formal akan tetapi juga melalui orang tua, masyarakat, tokoh adat, dan lingkungan.

Hal yang dapat dilakukan ialah aksi nyata untuk mengangkat kembali nilai-nilai kearifan lokal seperti Gurindan Dua Belas sebagai sumber inovasi melalui pendidikan berbasis budaya masyarakat lokal, dengan cara melakukan pemberdayaan melalui adaptasi pengetahuan lokal. Cara terbaik untuk bisa menggalakkan kembali nilai-nilai kearifan lokal yang terdapat di Kota Tanjungpinang ialah dengan memasukan Gurindam Dua Belas masuk sebagai pembelajaran muatan lokal. Artinya setiap isi dari gurindam dua belas ini diterapkan sebagai pembelajaran karakter bernuansa kearifan lokal. Hal ini dilakukan oleh pemerintah setempat guna melestarikan berbagai budaya dimana budaya memiliki kaitan erat dengan dunia pendidikan maupun agama. Artinya dengan adanya budaya maka dapat menunjang berjalannya sistem pendidikan yang berahlak mulia yang terdapat diantara peserta didik, guru, orang tua, dan orangorang yang terkait di dalamnya.

Jika kita melihat dan memasuki ruang-ruang kelas sekolah yang ada di Kota Tanjungpinang maka dipastikan akan ada tulisan-tulisan Gurindam Dua Belas dalam bentuk foster dan berpasangan dengan gambar Raja Ali Haji. Namun hal yang perlu dari semuanya itu bukanlah berhenti hannya disitu. Peran guru sangat dibutuhkan untuk mengajarkan apa-apa saja nilainilai yang terkandung di dalam isi setiap pasal Gurindam Dua Belas tersebut. Guru harus mengajarkan apa saja dampak negatif bagi kita apabila melakukan hal itu dan apa manfaatnya 
jika isi pasal itu dilaksanakan. Berikut merupakan isi dari Gurindam Dua Belas yang perlu direvitalisasi sebagai pembelajaran berbasis kearifan lokal di Kota Tanjungpinang.

\subsection{Gurindam Dua Belas Karya Raja Ali Haji}

\section{Pasal Pertama}

$>$ Barang siapa tiada memegang agama Sekali kali tidak boleh dibilangkan nama.

$>$ Barang siapa mengenal yang empat Maka ia itulah orang yang ma'rifat.

$>$ Barang siapa mengenal diri Maka telah mengenal Tuhan yang bahri.

$>$ Barangsiapa yang mengenal dunia Maka taulah dia barang yang terperdaya.

$>$ Barangsiapa yang mengenal akhirat Maka tahulah dia barang yang mudharat.

\section{Pasal Kedua}

$>$ Barang siapa mengenal yang tersebut Tahulah dia makna takut.

$>$ Barangsiapa meninggalkan sembahyang Bagai rumah tiada bertiang.

$>$ Barangsiapa meninggalkan puasa Tidaklah mendapat dua termasya.

$>$ Barangsiapa meninggalkan zakat Tiadalah hartanya beroleh berkat.

> Barangsiapa meninggalkan haji Tiadalah ia menyempurnakan janji. Pasal Ketiga

$>$ Apabila terpelihara mata Sedikitlah cita cita.

$>$ Apabila terpelihara kuping Kabar yang jatuh tiadalah dumping.

$>$ Apabila terpelihara lidah Niscahya dapat daripadanya faedah.

$>$ Bersungguh sungguhlah engkau memeliharakan tangan Dari pada segala berat dan ringan.

$>$ Apabila perut terlalu penuh Keluarlah fiil yang tiada senonoh

$>$ Anggota tengah hendaklah ingat Disitulah banyak orang yang hilang semangat.

$>$ Hendaklah pelihara kaki Daripada berjalan membawa rugi. Pasal Keempat

$>$ Hati itu kerajaan dalam tubuh Jikalau zalim segala anggotapun rubuh.

$>$ Apabila dengki sudah bertanah Datanglah daripadanya beberapa anak panah.

$>$ Mengumpat dan memuji hendaklah pikir Karena disitu banyak orang yang tergelincir.
$>$ Pekerjaan marah jangan di bela Nanti hilang akal di kepala.

$>$ Jika sedikitpun berbuat bohong Maka dapat diumpamakan mulutnya itu pekung.

$>$ Tanda orang yang amat celaka Aib dirinya tiada ia sangka

$>$ Bakhil jangan diberi singgah Itulah perompak yang amat gagah.

> Barangsiapa yang sudah besar Janganlah kelakuannya membuat kasar.

$>$ Barangsiapa perkataan kotor Maka mulutnya bagaikan ketor.

$>$ Dimana tau salah diri Jika tidak orang lain yang berperih.

$>$ Pekerjaan takabur jangan direpih Sebelum mati didapat juga sepih.

\section{Pasal Kelima}

$>$ Jika hendak mengenal orang yang berbangsa

Lihatlah budi dan bahasa.

$>$ Jika hendak mengenal orang yang berbahagia Sangat memeliharakan yang sia sia.

> Jika hendak melihat orang mulia Lihat pada kelakuan dia.

$>$ Jika hendak mengenal orang yang berilmu Bertanya dan belajar tiadalah jemu.

$>$ Jika hendak mengenal orang yang berakal Di dalam dunia mengambil bekal.

$>$ Jika hendak melihat orang yang baik perangai

Lihat pada ketika bercampur dengan orang ramai.

\section{Pasal Keenam}

$>$ Carilah olehmu akan sahabat Yang boleh dijadikan obat.

$>$ Carilah olehmu akan guru Yang boleh tahukan tiap seteru.

> Carilah olehmu akan istri Yang boleh menyerahkan diri.

$>$ Carilah olehmu akan kawan Pilih segala orang yang setiawan. Carilah olehmu akan abdi Yang ada baik sedikit budi. Pasal Ketujuh

$>$ Apabila banyak berkata kata Disitulah jalan masuk dusta.

> Apabila banyak berlebih lebih suka Itulah tanda hampirkan duka.

$>$ Apabila kita kurang siasat Itulah tanda pekerjaan hendak sesat.

$>$ Apabila anak tidak dilatih Jika besar bapanya letih.

> Apabila banyak mencela orang Itulah tanda dirinya kurang. 
$>$ Apabila orang banyak tidur Sia sia sahajalah umur.

$>$ Apabila mendengar akan kabar Menerimanya hendaklah sabar.

$>$ Apabila mendengar akan aduan Membicarakannya itu hendaklah cemburuan.

> Apabilah perkataan lemah lembut Lekaslah segala orang mengikut.

$>$ Apabila perkataan yang amat kasar Lekaslah segala orang mengikut.

$>$ Apabila perkataan yang amat kasar Lekaslah orang sekalian gusar.

$>$ Apabila pekerjaan yang amat benar Tidak boleh orang berbuat honar.

\section{Pasal Kedelapan}

$>$ Barangsiapa khianat akan dirinya Apalagi kepada lainnya.

$>$ Kepada dirinya ia aniaya Orang itu jangan engkau percaya.

$>$ Lidah yang suka membenarkan dirinya Dariapada yang lain dapat kesalahannya.

$>$ Daripada memuji diri hendaklah sabar Biar daripada orang dating kabar.

$>$ Orang yang suka menampakan jasa Setengah daripada syirik mengaku kuasa.

$>$ Kejahatan diri sembunyikan Kebajikan diri diamkan.

$>$ Keaiban orang jangan dibuka Keaiban diri hendaklah sangka.

\section{Pasal Kesembilan}

$>$ Tahu pekerjaan tak baik tetapi dikerjaikan Bukannya manusia yaitulah syaitan.

$>$ Kejahatan seorang perempuan tua Itulah Iblis punya penggawa.

$>$ Kepada segala hamba hamba raja Disitulah syaitan tempatnya manja.

$>$ Kebanyakan orang yang muda mudi Disitulah syaitan tempat bergoda.

> Perkumpulan laki-laki dengan perempuan Disitulah syaitan punya jamuan.

$>$ Adapun orang tua yang hemat Syaitan tak suka membuat sahabat.

$>$ Jika orang muda kuat berguru Dengan syaituan jadi seteru. Pasal Kesepuluh

$>$ Dengan bapa jangan durhaka Supaya Tuhan Yang maha Esa tidak murka.

$>$ Dengan ibu hendaklah hormat Supaya badan dapat selamat.

$>$ Dengan anak janganlah lalai Supaya boleh naik ke tengah balai.

$>$ Dengan kawan hendaklah adil Supaya tangannya jadi kapil.

\section{Pasal Kesebelas}

> Hendaklah berjasa kepada yang sebangsa.

Hendaklah jadi kepala buang Perangai yang cela.

$>$ Hendaklah memegang amanat Buanglah khianat.

Hendak marah dahulukan hujah.

$>$ Hendak dimalui jangan melalui Hendak ramai murahlah perangai.

\section{Pasal Kedua Belas}

$>$ Raja mufakat dengan menteri Seperti kebun berpagarkan duri Betul hati kepada raja Tanda jadi sebarang kerja.

$>$ Hukum adil atas rakyat Tanda raja beroleh inayat Kasihkan orang yang berilmu Tanda rahmat atas dirimu.

$>$ Hormat akan orang yang pandai Tanda mengenal kasa dan cindai Ingatkan dirinya mati Itulah asal berbuat bakti.

$>$ Akhirat itu terlalu nyata Kepada hati yang tiada buta.

\subsection{Nilai Agama, Pendidikan, dan Budaya yang dapat Diambil dari Gurindam Dua Belas Pasal $1-12$}

Gurindam Dua Belas sangat perlu direvitalisasi mengingat nilai-nilai yang terkandung di dalamnya memiliki tuntutan moral, pendidikan karakter, etika, norma, yang berlandaskan agama Islam.

Nilai dan pesan yang lebih terperinci dari pasal satu sampai pasal ke dua belas pada isi Gurindam Dua Belas ialah, pasal satu, memberikan nasihat kepada masyarakat tentang agama. Nilai yang terkandung pada pasal kedua ialah, menceritakan tentang orang - orang yang meninggalkan sembahyang, puasa, zakat, dan haji beserta akibatnya. Nilai yang terkandung pada pasal ketiga ialah, tentang budi pekerti, yaitu menahan kata-kata yang tidak perlu dan makan seperlunya.

Nilai yang terkandung pada pasal ke empat ialah, tentang tabiat yang mulia, yang muncul dari hati (nurani) dan akal pikiran (budi). Nilai yang terkandung pada pasal kelima ialah, tentang pentingnya pendidikan dan memperluas pergaulan dengan kaum terpelajar. Sedangkan nilai yang terkandung pada pasal keenam ialah, tentang pergaulan, yang menyarankan untuk mencari sahabat yang baik, demikian pula guru sejati yang dapat mengajarkan mana yang baik dan buruk. 
Berikutnya nilai yang terkandung pada isi pasal ke tujuh ialah, berisi nasihat agar orang tua membangun akhlak dan budi pekerti anakanaknya sejak kecil dengan sebaik mungkin. Jika tidak, kelak orang tua yang akan repot sendiri. Sedangkan nilai yang terkandung pada isi pasal kedelapan ialah, berisi nasihat agar orang tidak percaya pada orang yang tidak jelas dan tidak berprasangka buruk terhadap seseorang. Berikutnya ialah nilai yang terkandung pada isi pasal ke sembilan ialah, berisi nasihat tentang moral pergaulan pria wanita dan tentang pendidikan. Hendaknya dalam pergaulan antara pria wanita ada pengendalian diri dan setiap orang selalu rajin beribadah agar kuat imannya.

Selanjutnya nilai yang terkandung pada isi pasal ke sepuluh ialah, berisi nasihat keagamaan dan budi pekerti, yaitu kewajiban anak untuk menghormati orang tuanya. Sedangkan nilai yang terkandung pada isi pasal ke sebelas ialah, berisi nasihat kepada para pemimpin agar menghindari tindakan yang tercela, berusaha melaksanakan amanat anak buah dalam tugasnya, serta tidak berkhianat. Sedangkan nilai yang terkandung pada pasal terakhir yakni ke dua belas ialah, berisi nasihat keagamaan, agar manusia selalu ingat hari kematian dan kehidupan di akhirat.

Sesuai dengan prinsip gurindam, yaitu setiap lirik pertama yang terdapat di pasal dapat diartikan sebagai syarat, sedangkan lirik kedua dapat diartikan sebagai jawaban yang menjelaskan hal-hal apa saja yang akan terjadi pada seseorang apabila melakukan isi dari lirik pertama.

\section{KESIMPULAN}

Gurindam Dua Belas merupakan salah satu bentuk kearifan lokal dari Propinsi Kepulauan Riau karya Raja Ali Haji. Terdapat berbagai pesan moral dalam setiap bait dari isi Gurindam Dua Belas. Pesan-pesan tersebut ada yang bersendikan nilai-nilai religi, pendidikan, kebudayaan, hukum, dan politik. Berbagai pesan dan himbauan yang terkandung di dalamnya mengajarkan berbagai nilai dan etika bagaimana orang tua berperilaku yang baik kepada anak dan demikian sebaliknya. Pada sisi lain juga terdapat pesan moral, nasihat, pedoman hidup, yakni bagaimana cara beribadah yang baik kepada Tuhan Yang Maha Esa, bagaimana raja atau tuan menghormati masyarakat borjuis, dan terkait dengan kewajiban -kewajiban kita sebagai manusia kepada sesama kita, dan Tuhan Yang Maha Esa. Gurindan Dua Belas sangatlah baik dijadikan sebagai salah satu jenis pembelajaran muatan lokal dalam pendidikan formal. Hal ini diharapkan dapat memberikan rasa kecintaan para generasi muda etnis Melayu terhadap nilai-nilai kearifan lokal warisan nenek moyang terdahulu.

\section{REFERENSI}

Cecep, R., Permana, E., Nasution, I. P., \& Gunawijaya, J. (2011). PADA MASYARAKAT BADUY Local- wisdom of Disaster Mitigation on Baduy Abstract, 15(1), 67-76.

Drew, J. A. (2005). Use of Traditional Ecological Knowledge in Marine Conservation, 12861293. http://doi.org/10.1111/j.15231739.2005.00158.x

Dwyer, P. D. (1994). Modern conservation and indigenous peoples : in search of wisdom, 1 , 91-97.

Friedlander, A. M., Shackeroff, J. M., \& Kittinger, J. N. (2013). Customary Marine Resource Knowledge and Use in Contemporary, 67(3), 441-460. http://doi.org/10.2984/67.3.10

Gobyah, K. I. (2003). Berpijak pada Kearifan Lokal. http://www.balipos.co.id.

Jim, 2. Ife. (2002). Community Development, Creating Community Alternatives. Longman.

Kartawinata, A. M. (Penyunting). (2011). Merentas kearifan lokal di tengah modernisasi dan tantangan pelestarian. Jakarta

Koenttjaraningrat. (2009). Pengantar Ilmu Antropologi. Jakarta : Rineka Cipta

Sartini. (2004). Menggali Kearifan Lokal Nusantara Sebuah Kajian Filsafati. Jurnal Filsafat. Retrieved from Yogyakarta

Sartini. (2004). Menggali Kearifan Lokal Nusantara Sebuah Kajian Filsafati. Jurnal Filsafat. Retrieved from Yogyakarta

Sirtha, I. N. (2003). " Pelestarian Warisan Budaya Berbasis Desa Adat". Dinamika Kebudayaan, 5(1), 31-37.

Suryani, I. (2014). KEARIFAN LOKAL SUKU BADUY ( Studi Kasus Pada Acara Feature Dokumenter "Indonesia Bagus" di Stasiun Televisi NET . TV ), 13(2).

Sugiyono. 2013. Metode Penelitian Pendidikan Pendekatan Kuantitatif, Kualitatif dan R\&D. Bandung: Alfabeta. 